\title{
SPECTROPHOTOMETRIC DETERMINATION OF SOME PHARMACEUTICAL COMPOUNDS USING 2,2-DIPHENYL-1-PICRYLHYDRAZYL
}

\author{
Hesham Salem \\ Analytical Chemistry Department, Faculty of Pharmacy, Minia \\ University, Minia, EGYPT.
}

\section{ABSTRACT}

A simple, rapid and sensitive spectrophotometric procedure for the assay of some drugs has been developed. The method is based on the reaction of the studied drugs with 2,2-diphenyl-1picrylhydrazyl (DPPH). The latter is employed to abstract a hydrogen atom from the drugs thereby promoting a process of radical coupling. This results in a reduction of the violet color of DPPH with the formation of the yellow colored 2,2-diphenyl-1picrylhydrazine $\left(\mathrm{DPPH}_{2}\right)$. The decrease in the intensity of the violet color is used to measure the concentration of the drugs. All measurements are made at $\lambda=520 \mathrm{~nm}$ on methanolic solutions of the reagent and drugs. Beer's law is obeyed in the ranges of 5-30 $\mu \mathrm{g} / \mathrm{ml}$ (for aceclofenac, diclofenac sodium and thiaprofenic acid), $2-15 \mu \mathrm{g} / \mathrm{ml}$ (for tenoxicam, furosemide and lansoprazole) and 2-12 $\mu \mathrm{g} / \mathrm{ml}$ (for benoxinate hydrochloride and ritodrine). The validity of the method was tested by carrying out standard addition procedure analyzing the studied drugs in pure form as well as in their pharmaceutical preparations without interference from common additives. Results of the proposed methods are in good agreement with those of the official or reported methods.

\section{INTRODUCTION}

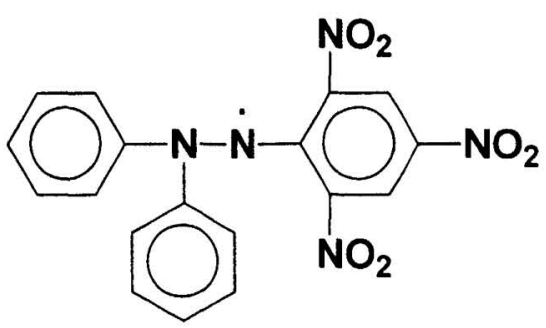

\section{DPPH}

2,2- Diphenyl-1-Picrylhydrazyl (DPPH) is an intense, violetcolored, stable, free radical which reacts as a chromogenic 
reagent ${ }^{1,2}$ by abstracting a hydrogen atom from the analyt to form yellow colored N,N-diphenylpicrylhydrazine $\left(\mathrm{DPPH}_{2}\right)$. This decrease in the intensity of the violet color is used as a measure of the quantity of the tested drugs. The radical DPPH was chosen for the present work because it does not dimerize ${ }^{3}$ and the problem of cage effect does not arise. In addition, it is deeply colored and its concentration at any time can be estimated by its absorption in the visible range $e^{4}$.<smiles>CC(C(=O)O)c1ccc(C(=O)c2ccccc2)s1</smiles>

Thiaprofenic acid

Thiaprofenic acid is an anti-inflammatory, antipyretic drug with analgesic properties. Its chemical structure is 2-(5-benzoyl-2thienyl)propionic acid. Several techniques were used for the determination of this drug such as spectrophotometric ${ }^{5}$, polarographic ${ }^{6}$, nuclear magnetic resonance ${ }^{7}$, high pressure liquid chromatographic ${ }^{8,9}$ and atomic absorption spectrophotometric methods ${ }^{10}$.<smiles>O=C(O)COC(=O)Cc1ccccc1Nc1c(Cl)cccc1Cl</smiles>

\section{Aceclofenac}

Aceclofenac has potent analgesic, anti-inflammatory and antipyretic effects. Its chemical structure is 2-[\{2-(2-)(2,6- dichlorophenyl)amino)1-phenyl)acetyl\}oxy]acetic acid. Determination of aceclofenac using adsorptive stripping voltammetric techniques on conventional and surfactant chemically modified carbon paste electrodes have been reported ${ }^{11}$. 


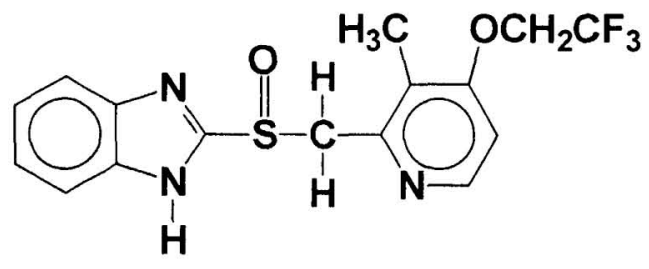

\section{Lansoprazole}

Lansoprazole is a substituted benzimidazole, it is one of the first drugs of a new class of orally active anti-ulcer agents. Its chemical structure is 2-[[[3-methyl-4-(2,2,2-trifluoroethoxy-2pyridinyl]methyl]sulfinyl]-1H-benzimidazole. Several chromatographic $^{12-14}$ and spectrophotometric ${ }^{15,16}$ techniques were used for its analysis.<smiles>CN1C(C(=O)Nc2ccccn2)=C(O)c2sccc2S1(=O)=O</smiles>

Tenoxicam

Tenoxicam is a potent non-steroidal, anti-inflammatory, antirheumatic and analgesic drug. Its chemical structure is 4-hydroxy2-methyl-N-(2-pyridyl)-2H-thieno[2,3-e]-1,2-thiazine-3-carboxamide1,1-dioxide. Polarographic ${ }^{17}$, spectrophotometric ${ }^{18,19}$ and chromat-ographic ${ }^{20,21}$ methods were recommended for the determination of tenoxicam.<smiles>CCCCOc1cc(C(=O)OCCN(CC)CC)ccc1N</smiles>

\section{Benoxinate hydrochloride}

Benoxinate hydrochloride is indicated as corneal anaesthesia of short duration. Its chemical structure is 2-(diethylamino)ethyl4-amino-3-n-butoxybenzoate hydrochloride. Spectrophotometric ${ }^{22}$ and pharmacological ${ }^{23}$ methods were recommended for the determination of benoxinate hydrochloride. 
<smiles>NS(=O)(=O)c1cc(C(=O)O)c(NCc2ccco2)cc1Cl</smiles>

Furosemide

Furosemide is the most potent diuretic available. It is therapeutically used in cases of acute pulmonary edema, acute renal failure and hypercalecemia. Its chemical structure is 4chloro-N-furfuryl-5-sulfamoyl anthranilic acid ${ }^{24}$. Pharmacological ${ }^{25}$, chrom-atographic ${ }^{26-28}$ and spectrophotometric ${ }^{29-33}$ methods have been reported for the assay of furosemide.<smiles>O=C(O)Cc1ccccc1Nc1c(Cl)cccc1Cl</smiles>

Diclofenac sodium

Diclofenac acid is widely used as an anti-inflammatory agent. Its chemical structure is [2-(2,6-dichloroanilinophenyl]acetic acid. Several techniques have been used for the determination of this drug including chromatographic ${ }^{34-36}$ and spectrophotometric methods ${ }^{33,37,38}$.<smiles>CC(NCCc1ccc(O)cc1)C(O)c1ccc(O)cc1</smiles>

Ritodrine

Ritodrine is [erythro-2-(4-hydroxyphenethylamino)-1-(4- hydroxyphenyl)propan-1-ol] is a sympathomimetic drug, used as an uterine relaxant drug. 
It inhibits the frequency and intensity of uterine contractions. Different methods, reported for determination of ritodrine, including pharmacological ${ }^{39}$, chromatographic ${ }^{40-43}$ and spectrophotometric techniques ${ }^{44}$.

In this work, a simple, rapid and sensitive spectrophotometric method is adopted for the determination of aceclofenac, thiaprofenic acid, tenoxicam, lansoprazole, furosemide, ritodrine, diclofenac sodium and benoxinate hydrochloride in the pure forms and in pharmaceutical preparations with 2,2-diphenyl-1-picrylhydrazyl (DPPH).

\section{EXPERIMENTAL}

\section{Apparatus}

A Shimadzu UV1601, UV-visible spectrophotometer (Tokyo, Japan) and Memert type thermostatically controlled water bath (Germany) were used. All volumetric measurements were made with standard glassware.

\section{Materials}

All solvents and reagents were of analytical reagent grade. The pharmaceutical grade pure drugs; aceclofenac was obtained from Bristol-Myers Squibb (Squibb, Egypt), furosemide, lansoprazole and thiaprofenic acid were obtained from Hoechst (Hoechst, Egypt), diclofenac sodium and ritodrine were obtained from Pharco (Pharco, Egypt) and benoxinate hydrochloride and tenoxicam were obtained from Eipico (E.I.P.I.Co, Egypt). All compounds were complying with requirements recommended by official or other reported methods and used as such without further purification. A standard stock solution of $50 \mathrm{mg} / 100 \mathrm{ml}$ of each studied drug was prepared in methanol.

\section{Reagents and solutions}

2,2-Diphenyl-1-picrylhydrazyl (Sigma, St.Louis, Mo, USA). A stock solution of $1.5 \mathrm{mg} / \mathrm{ml}$ was prepared by dissolving $0.15 \mathrm{~g}$ of DPPH in methanol and then diluted to $100 \mathrm{ml}$ with the same solvent. Ten milliliter of this solution were diluted to $100 \mathrm{ml}$ to give $0.15 \mathrm{mg} / \mathrm{ml}$ (working DPPH solution). The stock and working 
solutions were kept in a refrigerator and protected from light. The solution was found to be stable for at least one week at $4^{\circ} \mathrm{C}$. All chemicals and solvents were of analytical grades.

\section{Pharmaceutical preparations}

The commercial dosage forms subjected to analysis were Epicotil tablets (labeled to contain $20 \mathrm{mg}$ tenoxicam per tablet), Epicotil suppositories (labeled to contain $20 \mathrm{mg}$ tenoxicam per suppository) and Epicotil vials (labeled to contain $20 \mathrm{mg}$ tenoxicam per vial),E.I.P.I.Co, Egypt; Soral capsules (labeled to contain 20 $\mathrm{mg}$ tenoxicam per capsule) and Soral suppositories (labeled to contain $20 \mathrm{mg}$ tenoxicam per suppository), Global Napi Pharmaceuticals (under license of help Ltd-Greece); Benox ophthalmic solution (labeled to contain $4 \mathrm{mg}$ benoxinate hydrochloride per each ml), E.I.P.I.Co, Egypt; Lanzore capsules (labeled to contain $20 \mathrm{mg}$ lansoprazole per capsule), Hoechst Co., Egypt; Bristaflam tablets (labeled to contain $100 \mathrm{mg}$ aceclofenac per tablet), Squibb Co., Egypt; Surgam tablets (labeled to contain $100 \mathrm{mg}$ thiaprofenic acid per tablet), Surgam suppositories (labeled to contain $100 \mathrm{mg}$ tiaprofenic acid per suppository) and Surgam vials (labeled to contain $300 \mathrm{mg}$ thiaprofenic acid per vial), Hoechst Co., Egypt; Lasix tablets and ampoules were obtained from Hoechst Co., Egypt, labeled to contain $40 \mathrm{mg}$ and $20 \mathrm{mg}$ furosemide per tablet and ampoule, respectively. Declophen tablets and ampoules, Pharco Co., Egypt, labeled to contain $25 \mathrm{mg}$ and $75 \mathrm{mg}$ diclofenac sodium per tablet or ampoule respectively, were used. Yutopar tablets and ampoules (Pharco Co., Egypt), labeled to contain 10 $\mathrm{mg}$ of ritodrine hydrochloride per tablet and $1 \mathrm{ml}$ of ampoule, respectively, were used.

\section{General procedure}

Transfer $1 \mathrm{ml}$ of the investigated drug to a $10 \mathrm{ml}$ volumetric flask, add $2 \mathrm{ml}$ of DPPH solution. Mix well for lansoprazole and diclofenac sodium at $25^{\circ} \mathrm{C}$, heat in water bath at $60^{\circ} \mathrm{C}$ for 15 minutes for aceclofenac, thiaprofenic acid, furosemide and benoxinate hydrochloride and at $40^{\circ} \mathrm{C}$ for 10 minutes for tenoxicam and ritodrine. Cool and complete to the mark with methanol. Measure the absorbances of the sample and a reagent blank against methanol at $\lambda=520 \mathrm{~nm}$. Calculate $\Delta A$, i.e. the difference between the absorbance values of the blank and sample which corresponds to the drug concentration. 


\section{Assay of pharmaceutical preparations:}

\section{Assay of tablets}

Twenty tablets were accurately weighed and finely powdered. An amount equivalent to about $50 \mathrm{mg}$ of each drug was weighed accurately. The powder was transferred to $100 \mathrm{ml}$ volumetric flask, extracted successively three times with $10 \mathrm{ml}$ of methanol and completed to the mark with the same solvent. The extract is diluted to obtain $50 \mu \mathrm{g} / \mathrm{ml}$ before carrying out the general procedure.

\section{Assay of capsules}

The contents of twenty capsules were weighed and finely powdered. An amount equivalent to $50 \mathrm{mg}$ of each drug was weighed accurately and transferred into a $100 \mathrm{ml}$ volumetric flask. Thirty milliliter of methanol are added to the flask, which was shaken for $10 \mathrm{~min}$. The methanolic supernatant solution is filtered into a $100 \mathrm{ml}$ volumetric flask. The extraction is repeated twice and the content of the volumetric flask is diluted to volume with the same solvent. An accurately measured volume of this solution is pipetted into $10 \mathrm{ml}$ volumetric flasks then completed as under general procedure.

\section{Assay of suppositories:}

Five suppositories for each drug were accurately weighed and cut into small pieces. The suppository mass was transferred into a porcelain dish and melted on a boiling water bath to complete homogenity. An amount of the suppository mass equivalent to $50 \mathrm{mg}$ of each drug was mixed with $25 \mathrm{ml}$ methanol and shaken for $5 \mathrm{~min}$. The solution was filtered into a $100 \mathrm{ml}$ volumetric flask and completed to volume with methanol and completed as under general procedure.

\section{Assay of ampoules and eye drops}

Aliquot of ampoules or eye drops equivalent to $50 \mathrm{mg}$ of each drug was transferred into a $100 \mathrm{ml}$ volumetric flask and completed to volume with methanol and completed as under general procedure. 


\section{RESULTS AND DISCUSSION}

The ultraviolet-visible spectra of the assay solution of one of the tested drugs, DPPH and DPPH ${ }_{2}$ are shown in Figure 1. The reaction is assumed to proceed via abstraction of hydrogen atoms from the drugs by DPPH ${ }^{45}$. This is accompanied by the change of violet color of DPPH to give the yellow colored $\mathrm{DPPH}_{2}$ and the corresponding free radical of the drug (Scheme 1 ).

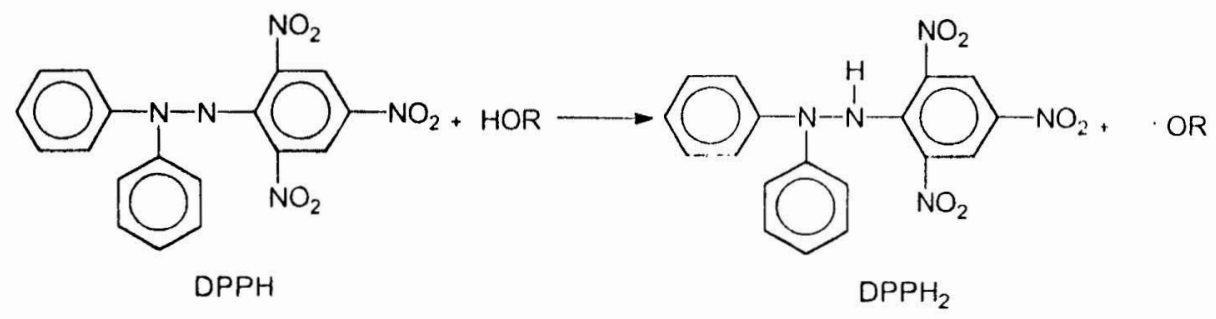

Scheme 1

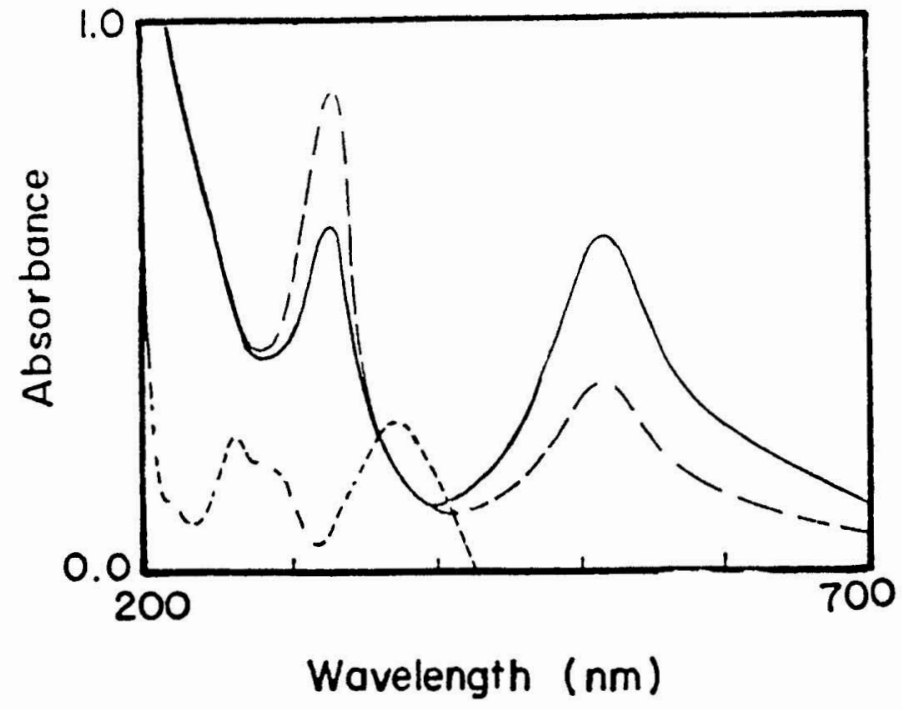

Fig.1: Absorption spectra of(-) DPPH, 30 $\mu \mathrm{g} / \mathrm{ml}$, reaction mixture of DPPH tenoxicam $(15 \mu \mathrm{g} / \mathrm{ml})(---)$ and tenoxicam $15 \mu \mathrm{g} / \mathrm{ml}(\cdots \cdots)$ 


\section{Optimization of variables:}

\section{Reagent concentration}

DPPH is added in excess to react with drugs to be analyzed. By measuring the excess reagent, the consumed DPPH would correspond to the amount of the drug.

The concentration of the reagent that gives the highest absorption value within the participle sensitivity range of absorbance was found to be $0.15 \mathrm{mg} / \mathrm{ml}$. Two milliliters of this solution per $10 \mathrm{ml}$ of the reaction mixture was used.

\section{Reaction time and temperature}

The reaction time was determined for the interaction of each studied drug with DPPH solution by following the color reduction at ambient temperature $\left(25 \pm 2{ }^{\circ} \mathrm{C}\right), 30,40,50$ and $60^{\circ} \mathrm{C}$.

The optimum temperature and reaction time were recorded in table 1 . The $\triangle \mathrm{A}$ reached a constant level, at once and remained constant for at least 180 minutes.

\section{Molar ratio of the reaction}

The stoichiometry of the reaction was assessed by the moleratio method ${ }^{46}$ and the results have been appeared in Table 1. Such results obtained have been cover the number of abstractable hydrogen present in the drug molecule.

Table 1. Assay parameters of the studied drugs.

Drug

Heating time Temp.

Molar ratio of

(min.)

$\left({ }^{\circ} \mathrm{C}\right)$

Drug-DPPH

\begin{tabular}{llcl}
\hline Ritodrine & 10 & 40 & $1: 2$ \\
Furosemide & 15 & 60 & $1: 1$ \\
Diclofenac sodium & - & 25 & $1: 1$ \\
Aceclofenac & 15 & 60 & $1: 1$ \\
Lansoprazole & - & 25 & $1: 1$ \\
Tenoxicam & 10 & 40 & $1: 2$ \\
Thiaprofenic acid & 15 & 60 & $1: 1$ \\
Benoxinate hydrochloride & 15 & 60 & $1: 1$ \\
& & & \\
\hline
\end{tabular}

* Equimolar concentration $=4 \times 10^{-4} \mathrm{M}$ 


\section{Influence of solvents}

The effect of dilution of the reaction product by different solvents namely, methanol, ethanol, n-propanol, isopropanol, nbutanol, acetone was studied. The results indicated that all solvents had no effect on the position of maximum absorption while the reactivity ( $\triangle A$ value) was affected. Methanol was found to be the most suitable solvent.

\section{Quantification}

Under the optimum parameters, Beer's law was obeyed for all studied drugs in the range shown in Table 2. The regression analysis of $\triangle A$ value versus concentration were done for all the studied drugs according to the linear regression equation summarized in Table 2.

Table 2. Spectral characteristics of the studied drugs by the proposed method.

\begin{tabular}{lcccc}
\hline Drug & $\begin{array}{c}\text { Drug Linear } \\
\text { range } \\
(\mathrm{Ug} / \mathrm{ml})\end{array}$ & $\mathrm{B}$ & $\mathrm{K}$ & $\mathrm{R}$ \\
\hline Ritodrine & $2-12$ & 0.0012 & 0.1545 & 0.9999 \\
Furosemide & $2-15$ & -0.0215 & 0.2547 & 0.9997 \\
Diclofenac sodium & $5-30$ & -0.1254 & 0.1589 & 0.9994 \\
Aceclofenac & $5-30$ & 0.0100 & 0.1478 & 0.9995 \\
Lansoprazole & $2-15$ & 0.0033 & 0.1235 & 0.9996 \\
Tenoxicam & $2-15$ & 0.0147 & 0.2154 & 0.9999 \\
Thiaprofenic acid & $5-30$ & 0.0121 & 0.1963 & 0.9996 \\
Benoxinate HCl & $2-12$ & -0.0951 & 0.1157 & 0.9991 \\
& & & & \\
\hline
\end{tabular}

B: Intercept, K: Slope and R: Correlation coefficient

\section{Effect of $\mathrm{pH}$}

The effect of $\mathrm{pH}$ of the added acetate buffer on color reduction was studied for the investigated drugs. The results revealed that the reaction was independent on $\mathrm{pH}$. Because of this independence of the reaction on $\mathrm{pH}$, further investigations were not carried out to establish whether the constituents or $\mathrm{pH}$ range 
of the buffer solutions have any effect on the interaction of DPPH with the investigated drugs.

\section{Interference}

Before proceeding with the analysis of the studied drugs in dosage forms, interference abilities from added common excipients ( such as lactose, sucrose, starch, magnesium stearate and gum acacia) were carried out to explore their effect. Samples were prepared by mixing known amounts of the investigated drugs with various amounts of the common excipients.

The good percentage recoveries of the investigated drugs obtained from those synthetic mixtures show that no interference from these additives takes place with the proposed method. Moreover, accuracy of the suggested procedure was further checked by applying standard addition technique.

The results obtained (Table 3 ) reveal a high degree of accuracy.

Table 3. Assay of the studied drugs in presence of common excipents by the proposed method applying the standard addition technique.

\begin{tabular}{|c|c|c|c|c|}
\hline \multirow[b]{2}{*}{ Drug } & \multicolumn{4}{|c|}{ Recovery $\% \pm$ S.D. } \\
\hline & $\begin{array}{c}\text { Sucrose } \\
20 \mathrm{mg}^{*}\end{array}$ & $\begin{array}{l}\text { Glucose } \\
10 \mathrm{mg} \text { * }\end{array}$ & $\begin{array}{l}\text { Lactose } \\
10 \mathrm{mg}^{*}\end{array}$ & $\begin{array}{l}\text { Starch } \\
\qquad 25 \mathrm{mg}^{\star}\end{array}$ \\
\hline Ritodrine & $99.1 \pm 0.25$ & $98.4 \pm 0.19$ & $99.3 \pm 0.75$ & $100.1 \pm 0.31$ \\
\hline Furosemide & $98.9 \pm 0.98$ & $99.2 \pm 0.69$ & $98.9 \pm 0.87$ & $99.6 \pm 0.39$ \\
\hline Diclofenac & $98.9 \pm 0.95$ & $99.8 \pm .0 .65$ & $99.9 \pm 1.20$ & $100.0 \pm 0.32$ \\
\hline Aceclofenac & $99.8 \pm 0.45$ & $99.8 \pm 0.26$ & $98.4 \pm 0.89$ & $99.9 \pm 0.98$ \\
\hline Lansoprazole & $100.1 \pm 0.88$ & $98.7 \pm 0.69$ & $99.5 \pm 0.78$ & $98.7 \pm 1.11$ \\
\hline Tenoxicam & $99.4 \pm 0.33$ & $98.7 \pm 0.78$ & $100.1 \pm 0.75$ & $98.1 \pm 0.22$ \\
\hline Thiaprofenic & $98.9 \pm 0.29$ & $99.4 \pm 0.37$ & $100.3 \pm 1.33$ & $98.1 \pm 0.87$ \\
\hline Benoxinate & $99.7 \pm 0.91$ & $100.6 \pm 0.81$ & $98.8 \pm 0.39$ & $99.7 \pm 0.87$ \\
\hline
\end{tabular}

* The amount of excipients added per $50 \mathrm{mg}$ of drug 


\section{Assay of pharmaceutical dosage forms}

It is evident from the results obtained previously that the proposed method gave satisfactory results with the drugs in bulk (Table 4). Thus different pharmaceutical formulations containing the investigated drugs were analyzed for the content of each drug by the proposed procedure as well as the official or reported methods. Data recorded in Table 4 showed no interference by excipients and additives. The results of the analysis recorded in Table 5 indicate the suitability of the method to the assay of the drugs in different pharmaceutical dosage forms. The calculated values of $F$ and $t$ (at $95 \%$ confidence level) did not exceed the tabulated (theoretical) ones. This means that there is no significant difference between the proposed and official or reported methods with respect to precision and accuracy.

Table 4. Recovery studies at different drug concentrations for all the studied drugs.

\begin{tabular}{|c|c|c|c|c|}
\hline$x^{-}$ & $\begin{array}{l}\text { Ritodrine } \\
10045\end{array}$ & $\begin{array}{c}\text { Furosemide } \\
9998\end{array}$ & $\begin{array}{c}\text { Benoxinate } \mathrm{HCl} \\
10002\end{array}$ & $\begin{array}{c}\text { Diclofenac sodium } \\
100.21\end{array}$ \\
\hline \pm S.D. & 0.35 & 0.81 & 0.71 & 0.61 \\
\hline RSD & 0.35 & 0.81 & 0.71 & 0.60 \\
\hline$N$ & 6 & 6 & 6 & 6 \\
\hline V & 0.12 & 0.66 & 0.50 & 0.37 \\
\hline & Aceclofenac & Lansoprazole & Tenoxicam & Thiaprofenic acid \\
\hline$X^{-}$ & 99.89 & 99.95 & 100.21 & 100.56 \\
\hline \pm S.D. & 0.94 & 0.97 & 0.61 & 0.74 \\
\hline RSD & 0.94 & 0.97 & 0.60 & 0.73 \\
\hline$N$ & 6 & 6 & 6 & 6 \\
\hline V & 0.88 & 0.94 & 0.37 & 0.55 \\
\hline
\end{tabular}

X: Mean, S.D.: Standard Deviation, RSD: Relative Standard Deviation, $\mathrm{N}$ : Number of experiments, V: Variance 
Table 5. Determination of the drugs in their pharmaceutical preparation by the proposed, reported and official methods.

\section{Pharmaceutical \\ Preparations}

\section{Recovery $\% \pm$ S.D.}

DPPH Official or

method Reported method
$F$

(3.58)

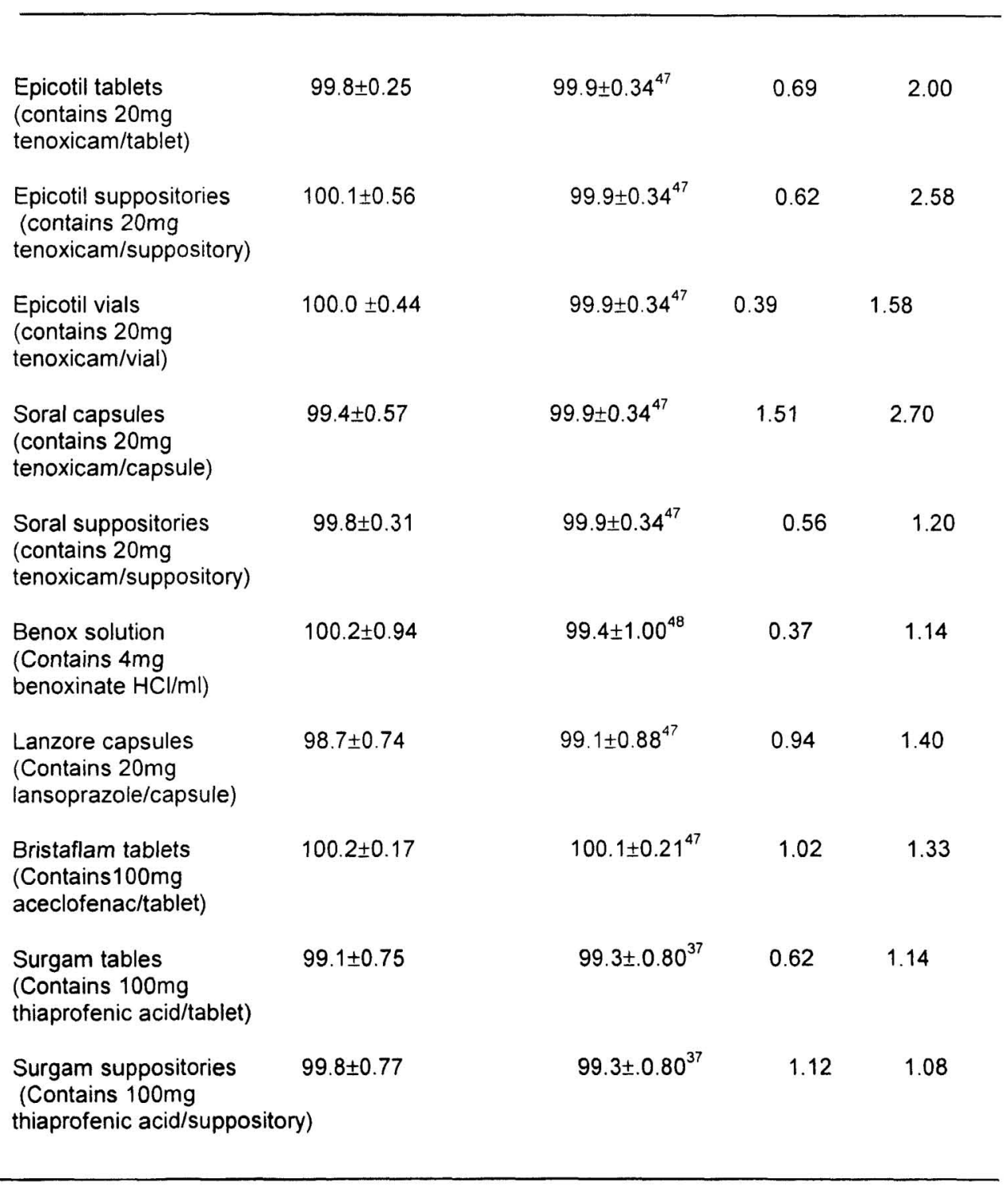


Continue Table 5. Determination of the drugs in their pharmaceutical preparations by the proposed, reported and official methods.

Pharmaceutical

Preparations
Recovery $\% \pm$ S.D.

DPPH Official or method Reported method
$F$

(4.28)
Surgam vials

(Contains $300 \mathrm{mg}$

thiaprofenic acid/vial)

Lasix tablets
(contains $40 \mathrm{mg}$
furosemide/tablet)
Lasix ampoules
(Contains $20 \mathrm{mg}$
furosemide/ampoule)
Declophen tablets
(Contains $25 \mathrm{mg}$
declofenac acid/tablet)
Declophen ampoules
(Contains $75 \mathrm{mg}$
declofenac acid/ampoule)
Yutopar tablets
(Contains $10 \mathrm{mg}$
ritodrin/tablet)
Yutopar ampoules
(Contains $10 \mathrm{mg}$
ritodrine/ampoule)

$99.6 \pm 0.89$

$99.3 \pm .0 .80^{37}$

0.58

1.23

$100.5 \pm 0.99$

$100.2 \pm 0.89^{24}$

0.52

$99.7 \pm 0.78$

$100.2 \pm 0.89^{24}$

1.11

$99.1 \pm 29$

$99.3 \pm 0.30^{37}$

1.19

2.25

$99.0 \pm 0.23$

$99.3 \pm 0.30^{37}$

2.25

1.80

$100.4 \pm 0.93$

$100.5 \pm 1.00^{37}$

0.19

1.16

$100.3 \pm 0.89$

In conclusion, the DPPH method is simple, sensitive, accurate and precise. It also has the advantage of being applicable to pharmaceutical preparations. In comparison to the official or reported methods, the DPPH method is rapid, specific and more sensitive. In addition, the DPPH reagent is stable, doesn't dimerize and is ready for use immediately and its reaction with the selected drugs is rapid and the reaction products are stable for more than two hours. 


\section{References}

1. Emara K.M.; (1988), Alex.J.Pharm.Sci.,11(2),179-181

2. Hosny E.S.; (1997), Bull.Pharm.Sci., 20(1),87-93

3. Braude E.A., Brook A.G. and Linsted R.P., (1954), J.Chem.Soc 3574

4. Papariello G.J. and Janish M.A.M., Anal.Chem., (1966), 38, 211

5. Ali A.M.M., Emara K.M. and Khodari M., (1994), Analyst, 119(5), 1071- 1074

6. Mohamed M.E., Wahbi A.A.M., Gad-Kariem E.R.A. and HassanM.M.A.,(1984),J.Assoc.offAnal.Chem.,67(4),684-687

7. Hassan M.M.A.and Ibrahim S.E., (1984), Spec.Lett.,19(7),719724

8. Jamali F., Russel A.S., Berry B.W. and Lechmann C., (1984), J.Chromatogr.Biomed.Appl.,35[2(J.Chromatogr.,310)], 327- 33

9. Muller N., Lapicque F., Drelon E., Gillet P., Monot C., Poletto B. and Netter P., (1993), J.Chromatogr.Biomed.Appl.,1127 [2(J.Chromatogr.,616)],261-270

10. Salem H. and Aboul Kheir A., (1995), Zag.J.Pharm.Sci., 4(1), 141-149

11. Posac J.R., Vazquez M.D., Tascon M.L., Acuna J.A., Delafuente C. and Sanchezbatanero P., (1995), Talanta, 42(2), 293-304

12. Argekar A.P. and Kunjir S.S., (1996), J.of Plan.Chromatogr., 9 (4), 296-299

13. Borner K., Borner E. and Lode H., (1997), Chromatographia, $45,450-452$

14. Borner K., Borner E. and Lode H., (1998), Chromatographia, 47(3-4)171-175

15. Ozaltin N., J.Pharm.Biomed.Anal., 1999, 20(3),599-606

16. Moustafa A.A., J.Pharm.Biomed.Anal.,2000, 22(1),45-58

17. Atkobar Z. and Tuncel M., (1996), Anal.Lett.,29(13),2383-2397

18. Atay O. and Dincol F., (1997), Anal.Lett., 30(9),1675-1684

19. Elries M.A., (1998), Anal.Lett., 31(5),793-807

20. Dixon J.S. , Lowe J.R. and Galloway D.B., (1984), J.Chromatogr., 310, 455-459

21. Day R.O., Lam S., Paul P. and Wade D., (1987),Br.J.Clin.Pharmac., 24,323-328

22. El-Gindy A., J.Pharm.Biomed.Anal.,2000, 22(2),215-234 
23. Kasuya F., Igarashi K. and Fukui M., J.Pharm.Sc.,1987, 76(4), 303-305

24. The Britich Pharmacopeia(1993), ; Her Majesty's Stationary Office:Cambridge.

25. LOu M., Garay R. and J.Alda O., (1991), J.Physiol., 443,123136

26. Yoshitomi H., Ikeda K. and Goto S., (1982), Yakugaku Zasshi., 102,1171-1176

27. Guermouche S., Guermouche M.H., Mansouri M. and Abed L., (1985), J.Pharm.Biomed.Anal., 3,435-458

28. Sangy M., Meuwly P., Munafo A. and Rivier L., (1991),J.Chromatogr., 564,567-578

29. Abdine H., El-Sayed M.A.H. and El-Sayed Y.M., (1978), J.Assoc.off Anal.Chem., 61,695-701

30. Issopoulos P.B., (1989), Fresenius.Z.Anal.Chem., 334,554557

31. Zivanovic L., Agatonovic S. and Radulovic D., (1990), Pharmazie, 45,935

32. Salem H., El-Maamli M., El-Sadek M. and Aboul Kheir A., (1991), Spec.Lett., 24,451-470

33. Salem H., (1995), Chin.Pharm.J., 3,263-272

34. Keith K.H., Kunjbala H. and Wnuck K., (1983), Anal.Lett., $15,1649-1663$

35. Geiger U.P., Degen P.H. and Sioufi A., (1975), J.Chromatogr., 111,293-298

36. Schweijer A., Willis J.V., Jack D.B. and Kendal M., (1980), J.Chromatogr., 195,421-424

37. Clarke's (1986), Isolation and Identification of Drugs, 2nd ed. The Pharmaceutical Press:London

38. El-Sadek M., (1991),Egypt J.Pharm.Sci., 32,457-463

39. Doganay T., Lundberg B., Sjoblom L. and Ataberk Z.P., (1989), Acta.Pharm.Suecica., 15,401-405

40. Kuhnert P., Erhard P., Dixon A., Kuhnert B. and Gross T., (1983), J.Liq. Chromatogr., 6,2775-2783

41. Lin L.S., Caritis S.N. and Wong L.K., (1984), J.Phram.Sci., 73,131-133

42. Gross A.S., Brown K.F., Baird J.A. and Nation R.L., (1987), J.Chromatogr.Biomed.Appl.,60(2(J.Chromatogr.,416)),400 408 
43. Wright M.R., Axelson J.E., Abbot F.S. and Riggs K.W., (1991),J.Chromatogr.Biomed.Appl., 103(1-2(J.Chromatogr., 565)),225 -236

44. Shalaby A. and Salem H., (1996), Scient.Pharma., 7,1-12

45. Forrester A.R., Hay J.M. and Thomson R.H., (1968), Organic Chemistry of Stable Free Radicals, Academic Press, London

46. Rose J.,(1964), J.Advanced PhysicoChemical Experiments, 54

47. The Britich Pharmacopeia; (1998), Her Majesty's Stationary Office: Cambridge.

48. The merk index (1983), an encyclopedia of chemicals, drugs and biologicals, tenth edition. 